\title{
In situ fortification of vitamin B12 in wheat flour and wheat bran by fermentation with Propionibacterium freudenreichii
}

\section{Xie, Chong}

2018-05-04

Xie , C, Coda , R, Chamlagain , B , Edelmann, M, Deptula, P, Varmanen, P, Piironen , $V$ \& Katina , K 2018 , ' In situ fortification of vitamin B12 in wheat flour and wheat bran by fermentation with Propionibacterium freudenreichii ' , Journal of Cereal Science, vol. 81, pp. 133-139 . https://doi.org/10.1016/j.jcs.2018.05.002

http://hdl.handle.net/10138/301439

https://doi.org/10.1016/j.jcs.2018.05.002

cc_by_nc_nd

acceptedVersion

Downloaded from Helda, University of Helsinki institutional repository.

This is an electronic reprint of the original article.

This reprint may differ from the original in pagination and typographic detail.

Please cite the original version. 


\section{Accepted Manuscript}

In situ fortification of vitamin B12 in wheat flour and wheat bran by fermentation with Propionibacterium freudenreichii

Chong Xie, Rossana Coda, Bhawani Chamlagain, Minnamari Edelmann, Paulina Deptula, Pekka Varmanen, Vieno Piironen, Kati Katina

PII: S0733-5210(18)30123-1

DOI: 10.1016/j.jcs.2018.05.002

Reference: YJCRS 2567

To appear in: Journal of Cereal Science

Received Date: 06 February 2018

Revised Date: 30 April 2018

Accepted Date: 03 May 2018

Please cite this article as: Chong Xie, Rossana Coda, Bhawani Chamlagain, Minnamari Edelmann, Paulina Deptula, Pekka Varmanen, Vieno Piironen, Kati Katina, In situ fortification of vitamin B12 in wheat flour and wheat bran by fermentation with Propionibacterium freudenreichii, Journal of Cereal Science (2018), doi: 10.1016/j.jcs.2018.05.002

This is a PDF file of an unedited manuscript that has been accepted for publication. As a service to our customers we are providing this early version of the manuscript. The manuscript will undergo copyediting, typesetting, and review of the resulting proof before it is published in its final form. Please note that during the production process errors may be discovered which could affect the content, and all legal disclaimers that apply to the journal pertain. 

$(6$

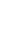

\section{In situ fortification of vitamin B12 in wheat flour and wheat bran by fermentation with Propionibacterium \\ freudenreichii}

Chong Xie*, Rossana Coda, Bhawani Chamlagain, Minnamari Edelmann, Paulina Deptula, Pekka Varmanen, Vieno Piironen, Kati Katina

Department of Food and Environmental Sciences, University of Helsinki, PO Box 66 FI-00014, Finland

*Corresponding author. Tel.: + 358449120811

E-mail address: chong.xie@helsinki.fi

Keywords: Propionibacterium freudenreichii; In situ fortification; Vitamin B12;

Wheat bran

1

\footnotetext{
1 Abbreviation: AA, Acetic Acid; CFU, Colony Forming Unit; DMBI, 5,6 dimethylbenzimidazole; dw, dry weight; HPLC, High-Performance Liquid Chromatography; LA, Lactic Acid; LAB, Lactic Acid Bacteria; MRS, de Man, Rogosa and Sharpe; PA, Propionic Acid; PCA, Plate Count Agar; TTA, Total Titratable Acid; VRBGA, Violet Red Bile Glucose Agar; YEL, Yeast Extract Lactate; YM, Yeast Mold.
} 

6

\section{Abstract}

Vitamin B12 is a micronutrient naturally existing in animal products. A growing interest and need to replace animal protein with plant protein sources have resulted in increased attention to developing vitamin B12-fortified plant-based food. Natural fortification by Propionibacterium freudenreichii is a promising alternative to chemical fortification, as P. freudenreichii can synthesize active vitamin B12. In this work, we studied vitamin B12 production in non-sterile matrices prepared from three raw materials of wheat: durum flour, wholewheat flour and wheat bran. Viable cell counts, $\mathrm{pH}$, total titratable acidity and concentration of acids were determined. After seven days of fermentation, vitamin B12 levels reached $33 \pm 4,87 \pm 10$ and $155 \pm 17$ $\mathrm{ng} / \mathrm{g}$ dry weight in durum flour, wholewheat flour, and wheat bran, respectively. While durum flour supported the growth of $P$. freudenreichii to higher cell densities and more efficient propionic acid production compared with the other two matrices, wholewheat flour and wheat bran were found to be the most promising of the three matrices for in situ production of vitamin B12.

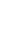

(1)




\section{Introduction}

Vitamin B12, also known as cobalamin, has the most complex chemical structure of all vitamins. Humans require it as a cofactor for two enzymes: cytoplasmic methionine synthase, which is involved in nucleotide synthesis together with folate, and for methylmalonyl-CoA mutase, which is important in the metabolism of oddchain fatty acids and branched amino acids (Nielsen et al., 2012). A vitamin B12 deficiency may result in health problems, such as megaloblastic anemia and various neurological disorders (Nielsen et al., 2012). A vitamin B12 intake of $2.4 \mu \mathrm{g} /$ day is recommended for adults according to the Institute of Medicine (1998).

Vitamin B12 is known to be synthesized by only a few microorganisms, such as Pseudomonas denitrificans, Bacillus megaterium, and Propionibacterium freudenreichii (Martens et al., 2002). Foods of animal origin are still the main dietary sources of vitamin B12, and without chemical supplementation or fortification due to fermentation, it is not present in appreciable amounts in foods of plant-origin (Watanabe, 2007). Vitamin B12 deficiency, mainly caused by inadequate dietary intake or malabsorption, is reported to be a problem worldwide (Green et al., 2017).

Developing plant products fortified with vitamin B12 is a promising way to ensure sufficient intake by people consuming limited amounts of animal products. As wheat is one of the most produced and important cereals for human diet, wheat products would be good candidates for delivering vitamin B12.

Specific strains of several Lactobacillus species have been reported to produce vitamin B12 (Bhushan et al., 2017; Taranto et al., 2003). However, the few studies 
employing methods capable of distinguishing between the different B12 forms indicate that Lactobacilli produce pseudovitamin B12 (Crofts et al., 2013; Santos et al., 2007). Pseudovitamin B12 differs from the active B12 by the presence of adenine in the place of 5, 6-dimethylbenzimidazole (DMBI) as the lower ligand and it is inactive in humans (Stupperich and Nexo, 1991; Watanabe, 2007). The ability of Lactobacillus strains to synthesize DMBI has not been addressed in detail yet. $P$. freudenreichii, a bacterium with generally recognized as safe status, synthesizes DMBI (Deptula et al., 2015) and produces the active form of vitamin B12 in nutritionally relevant amounts, also under food-like conditions (Chamlagain et al., 2016; Deptula et al., 2017a).

Some strains of $P$. freudenreichii have already been used in cereal-based food for various functions, such as producing exopolysaccharides or antifungal compounds (Denkova et al., 2014; Tinzl-Malang et al., 2015). Chamlagain et al. (2017) reported the production of $37 \mathrm{ng} / \mathrm{g}$ (fresh weight) of active vitamin B12 by P. freudenreichii in a sterilized barley-based matrix $(33 \% \mathrm{w} / \mathrm{v})$ after a 7 -day fermentation period. However, whether P. freudenreichii can produce physiologically significant amounts of vitamin B12 in unsterilized cereal matrices with autochthonous microbiota is still unknown. Moreover, to the best of our knowledge, there has been no published study on the in situ fortification of vitamin B12 in wheat matrices.

The aim of this work was to study the influence of three types of wheat raw materials (durum wheat flour, wholewheat flour, and wheat bran) on the in situ production of vitamin B12 by $P$. freudenreichii. Vitamin B12 enriched cereal raw 
material could be used for several plant based foods such as bread or extruded products. The acidification properties, microbial growth, and amounts of glucose and riboflavin, a precursor of DMBI, were monitored to follow the metabolism of $P$. freudenreichii during fermentation.

\section{Materials and methods}

\subsection{Raw materials}

Durum (Triticum durum) flour, obtained from Myllyn Paras (Hyvinkää, Finland), contained $14 \mathrm{~g}$ protein, $69 \mathrm{~g}$ carbohydrates ( $4 \mathrm{~g}$ fibers), $0.7 \mathrm{~g}$ ash and $2 \mathrm{~g}$ lipids per 100 g. Wholewheat (Triticum aestivum) flour was obtained from Helsinki Mylly Oy (Helsinki, Finland), and it contained $12 \mathrm{~g}$ protein, $72 \mathrm{~g}$ carbohydrates (12 $\mathrm{g}$ fibers), $2.1 \mathrm{~g}$ ash and $3 \mathrm{~g}$ lipids per $100 \mathrm{~g}$. Wheat (T. aestivum) bran, supplied by Lantmännen Cerealia AB (Malmö, Sweden), contained $14 \mathrm{~g}$ protein, $65 \mathrm{~g}$ carbohydrates (54 g fibers), $7.1 \mathrm{~g}$ ash and $6 \mathrm{~g}$ lipids per $100 \mathrm{~g}$.

\subsection{Culture preparation}

P. freudenreichii subsp. freudenreichii DSM 20271 that was cryopreserved ($70^{\circ} \mathrm{C}$ ) in $15 \%$ glycerol was propagated anaerobically for 4 days on a yeast extract lactate (YEL) agar (Malik et al., 1968). Three individual colonies were transferred into $30 \mathrm{ml}$ of YEL medium as three biological replicates and incubated at $30^{\circ} \mathrm{C}$. After $72 \mathrm{~h}$, cultures were recovered by centrifugation $(3,200 \times \mathrm{g}, 10 \mathrm{~min})$, resuspended in sterile water, and subsequently used for the inoculation of the doughs.

\subsection{Dough preparation and fermentation}

Three dough types were prepared by mixing MilliQ-water and flour according to 
108

109

110

the recipe given in Table 1. The proportions of flours were set so that the visually estimated viscosity in doughs was similar. Doughs $(30 \mathrm{~g})$ were weighed in Falcon tubes $(50 \mathrm{ml})$, and triplicate tubes were prepared for each time point (days $0,1,3$, and 7).

The doughs were inoculated with propagated cultures of $P$. freudenreichii, so that the cell count was approximately 9.0 log colony forming units (CFU)/g of dough. Since cobalt content in white flour is low in comparison to wholegrain or wheat bran (Ekholm et al., 2007) and availability of cobalt is a potential limiting factor during in situ production of vitamin B12, a durum dough enriched with $0.6 \mu \mathrm{g} / \mathrm{g}$ dry weight (dw) of cobalt(II) chloride (Sigma-Aldrich, Steinheim, Germany) was also prepared. In addition, control doughs of each dough type without inoculation were included in the study. The tubes were incubated at $25^{\circ} \mathrm{C}$ in shaking conditions $(200 \mathrm{rpm}$; Certomat) for up to 7 days. The tubes for day 7 were aseptically opened once on day 3 to allow air in and then closed because oxygen is required for the biosynthesis of DMBI (Deptula et al., 2015). At each time point (days 0, 1, 3, and 7), an aliquot of the samples was immediately taken out for the determination of viable cell counts and acidification properties. The rest of the samples were stored $\left(-20^{\circ} \mathrm{C}\right)$ for vitamin $\mathrm{B} 12$, total titratable acidity (TTA), riboflavin, glucose and acids analyses.

\subsection{Microbial counts}

Microbial counts were determined according to common plate count techniques and using different substrates for monitoring of different microbial groups as described by Coda et al. (2014) and Malik et al. (1968) with some modifications. 
130

131

132

Serial dilutions of doughs ( $10 \mathrm{~g})$ were carried out in sterile saline solution $(8.5 \mathrm{~g} / \mathrm{L}$ of $\mathrm{NaCl}$ ) and appropriate dilutions were plated on the appropriate plate. P. freudenreichii were determined on YEL plates incubated anaerobically (Anaerogen, Oxoid, Basingstoke, UK) for 4 days at $30^{\circ} \mathrm{C}$ and aerobically for at least 1 day, which leads the $P$. freudenreichii colonies to turn brownish and distinguishable from colonies of other bacteria. Presumptive LAB were enumerated on de Man, Rogosa and Sharpe (MRS) agar (Lab M, Lancashire, UK) at $30^{\circ} \mathrm{C}$ for $48 \mathrm{~h}$. Total aerobic bacteria were counted on PCA agar (Lab M) incubated at $30^{\circ} \mathrm{C}$ for $48 \mathrm{~h}$, and yeasts were cultivated at $30^{\circ} \mathrm{C}$ for $48 \mathrm{~h}$ on $\mathrm{YM}$ agar composed of $3 \mathrm{~g} / 1$ malt extract, $3 \mathrm{~g} / 1$ yeast extract, $5 \mathrm{~g} / 1$ peptone, $10 \mathrm{~g} / 1$ dextrose, and $0.01 \%$ chloramphenicol (Oxoid, Basingstoke, UK ) to prevent bacterial growth. The cell counts of Enterobacteriaceae were determined on VRBGA Agar (Lab M) after incubation at $37^{\circ} \mathrm{C}$ for $48 \mathrm{~h}$. The results were expressed in $\mathrm{CFU} / \mathrm{g}$ of dough.

\subsection{Acidification properties}

The $\mathrm{pH}$ values were determined using a $\mathrm{pH}$ meter (Portamess 752 Calimatic, Knick, Berlin, Germany). TTA was determined with a Mettler Toledo EasyPlus Titrator (Schott, Germany). Ten grams of dough mixed in $90 \mathrm{ml}$ of distilled water were titrated against $0.1 \mathrm{M} \mathrm{NaOH}$ to a final $\mathrm{pH}$ of 8.5. TTA was expressed as the volume of $0.1 \mathrm{M} \mathrm{NaOH}$ used (ml).

\subsection{Determination of $\alpha$-amylase, glucose and acids}


151 (Ceralpha, Megazyme Co., Ltd., Wicklow, Ireland), and the results were expressed in

Ceralpha units on a dry matter basis (Table 1). One unit of activity is defined as the amount of enzyme required to release $1 \mu \mathrm{mol}$ of glucose reducing-sugar equivalents in 1 minute under defined conditions.

Doughs $(1 \mathrm{~g})$ were diluted 1:10 $(\mathrm{w} / \mathrm{v})$ in water and centrifuged $(13,000 \times g, 10$ min). The supernatants were filtered $(0.45 \mu \mathrm{m}$, Pall, USA) into vials. Glucose, lactic acid (LA), acetic acid (AA), and propionic acid (PA) were determined using a highperformance liquid chromatography (HPLC) method described in Chamlagain et al. sodium acetate. Then, the extract was incubated $\left(\right.$ at $\left.37^{\circ} \mathrm{C}\right)$ with Taka-Diastase $(50 \mathrm{mg}$;

171 Pfaltz and Bauer, CT, USA) and $\beta$-amylase ( $5 \mathrm{mg}$; Sigma-Aldrich) for $24 \mathrm{~h}$. The 
172

173

174

extract was filtered $(0.2 \mu \mathrm{m}$, Pall, USA $)$ and analyzed on a Waters UPLC system with an Acquity BEH C18 column $(2.1 \times 100 \mathrm{~mm}, 1.7 \mu \mathrm{m})$ and a Waters fluorescence detector using aqueous methanol $(30 \% \mathrm{v} / \mathrm{v})$ containing $20 \mathrm{mM}$ ammonium acetate as an eluent $(0.2 \mathrm{ml} / \mathrm{min})$.

\subsection{Determination of vitamin B12}

Vitamin B12 was determined as cyanocobalamin in dough samples after extraction and purification as presented by Chamlagain, Edelmann, Kariluoto, Ollilainen and Piironen (2015) with minor modifications. In addition, the presence of other corrinoids, especially pseudovitamin B12, was followed in chromatograms based on the knowledge of their retention times and absorption spectra obtained in our previous studies (Chamlagain et al., 2015; Chamlagain et al., 2017; Deptula et al., 2017a; Deptula et al., 2015). Approximately $3 \mathrm{~g}$ of fermented doughs were mixed with $15 \mathrm{ml}$ of extraction buffer $(8.3 \mathrm{mM}$ sodium hydroxide and $20.7 \mathrm{mM}$ acetic acid, $\mathrm{pH} 4.5)$ containing $100 \mu \mathrm{l}$ of sodium cyanide ( $1 \% \mathrm{w} / \mathrm{v}$ in water) and extracted in boiling water for $30 \mathrm{~min}$. After cooling, $300 \mu \mathrm{l}$ of $\alpha$-amylase $(50 \mathrm{mg} / \mathrm{ml}$; St Louis, MO, USA) was added, and the samples were incubated in a water bath $\left(30 \mathrm{~min}, 37^{\circ} \mathrm{C}\right)$ to allow the breakdown of starch before centrifugation $(6,900 \times g, 10 \mathrm{~min})$. Residues after centrifugation were suspended in $5 \mathrm{ml}$ of extraction buffer and centrifuged again. After combining the supernatants, the final volume was adjusted to $25 \mathrm{ml}$ with the extraction buffer.

After filtration $(0.2 \mu \mathrm{m}$, Pall, USA), $10 \mathrm{ml}$ of the extracts was purified through an immunoaffinity column (Easi-Extract; R-Biopharma; Glasgow, Scotland) and 
analyzed with a Waters UHPLC system (Milford, MA, USA) equipped with a photodiode array detector (at $361 \mathrm{~nm})$ and an Acquity HSS T3 C18 column $(2.1 \times 100$ $\mathrm{mm}, 1.8 \mu \mathrm{m})$. The mobile phase was a gradient flow of acetonitrile and MilliQ water with $0.025 \%$ trifluoroacetic acid $(0.32 \mathrm{ml} / \mathrm{min})$ as explained by Chamlagain et al. (2015). Each sample was injected twice $(15 \mu 1)$.

\subsection{Reporting of results and statistical analysis}

Contents of glucose, acids, riboflavin, and vitamin B12 were reported on a dry matter basis. Statistical analysis was performed using SPSS 21.0 for Windows (IBM Corporation, NY, USA). One-way analysis of variance (ANOVA) and Tukey's post hoc test were employed to determine significant differences among the samples. The results were calculated based on three replicates, and the level of statistical significance was defined at a $p$-value $<0.05$.

\section{Results}

\subsection{Acidification and microbial counts}

Before fermentation, the $\mathrm{pH}$ value in the doughs ranged from 6.24 to 6.72 (Fig. 1A). In the first 3 days, the $\mathrm{pH}$ in all doughs decreased sharply. Generally, the $\mathrm{pH}$ in the inoculated doughs were higher than those in the control doughs. On day 1 , the $\mathrm{pH}$ of the wholewheat flour dough was the highest $(5.86 \pm 0.02)$, while it was the lowest in the durum flour control dough $(4.63 \pm 0.06)$. On day 3 , only in wheat bran doughs the $\mathrm{pH}$ was higher than 4.0. At the end of the fermentation, the $\mathrm{pH}$ of all doughs was lower than 4.0; the lowest value of 3.5 was reached in the durum doughs.

The initial TTAs in durum flour, wholewheat flour, and wheat bran doughs were 
216

217

$1.5 \pm 0.2 \mathrm{ml}, 2.7 \pm 0.2 \mathrm{ml}$, and $2.9 \pm 0.5 \mathrm{ml}$, respectively (Fig. 1B). During the fermentation, the TTA increased, and the inoculated doughs had higher TTA levels than the corresponding control doughs. The wheat bran dough had the highest TTA levels, which reached $24.8 \pm 0.2 \mathrm{ml}$ in the inoculated dough and $23.4 \pm 0.2 \mathrm{ml}$ in the control dough on day 7. In contrast, the durum flour control dough had the lowest TTA $(17.3 \pm 0.1 \mathrm{ml})$ on day 7 .

At the beginning of fermentation, the number of $P$. freudenreichii colony forming units in the inoculated doughs ranged from $8.7 \log \mathrm{CFU} / \mathrm{g}$ to $9.0 \log \mathrm{CFU} / \mathrm{g}$ (Table 2). After one day of fermentation the cell number of $P$. freudenreichii reached $9.6 \pm 0.1 \log$ and $9.4 \pm 0.1 \log \mathrm{CFU} / \mathrm{g}$ in durum flour dough and in wheat bran dough, respectively, and remained approximately at the level until the end of fermentation (day 7). In the wholewheat flour dough, the number of $P$. freudenreichii $\mathrm{CFU}$ remained stable during the fermentation. The low initial number of LAB $(<3 \log$ $\mathrm{CFU} / \mathrm{g}$ ) increased to $8.6 \pm 0.1 \log \mathrm{CFU} / \mathrm{g}$ in wholewheat flour doughs and $9.2 \log$ $\mathrm{CFU} / \mathrm{g}$ in other doughs after one day of fermentation. Similar LAB cell numbers were counted in doughs with and without $P$. freudenreichii. In doughs of durum flour and wheat bran the cell number of LAB remained stable after day 1. In wholewheat flour dough with $P$. freudenreichii, the cell density of LAB further increased to $9.0 \pm 0.1$ $\log \mathrm{CFU} / \mathrm{g}$ on day 3 and remained stable after that.

The inoculation of $P$. freudenreichii had no influence on the cell numbers of total aerobic bacteria, total Enterobacteriaceae, or yeasts. The cell density of the total aerobic bacteria in all doughs increased from approximately $4 \log \mathrm{CFU} / \mathrm{g}$ to $9 \log$ 
238

239

240

$\mathrm{CFU} / \mathrm{g}$ on the first day of fermentation and remained stable after that. The cell density of total Enterobacteriaceae ranged from $4.5 \pm 0.1 \log \mathrm{CFU} / \mathrm{g}$ to $4.9 \pm 0.1 \log \mathrm{CFU} / \mathrm{g}$ in all doughs before fermentation, and further, it grew 100-fold from days 0 to 1 . After day 1, the cell count of total Enterobacteriaceae decreased in all doughs, and Enterobacteriaceae were not found on day 7. The initial cell density of yeasts was approximately $3.8 \log \mathrm{CFU} / \mathrm{g}$ in durum flour dough and less than $2 \log \mathrm{CFU} / \mathrm{g}$ in the other doughs. The cell count of yeasts in all doughs increased to approximately 5.0 on day 1 , but decreased after that and became undetectable on day 7 .

\subsection{Glucose, $\alpha$-amylase activity and organic acids}

The $\alpha$-amylase activity in durum flour, wholewheat flour and wheat bran were 0.12 units/g, 0.19 units/g and 0.15 units $/ g$, respectively.

On day 0 , the glucose contents in durum flour, wholewheat flour, and wheat bran doughs were $8.5 \pm 0.4 \mathrm{mg} / \mathrm{g}, 18.4 \pm 1.2 \mathrm{mg} / \mathrm{g}$, and $26.8 \pm 1.1 \mathrm{mg} / \mathrm{g} \mathrm{dw}$, respectively (Fig. 2A). In the bran doughs, the glucose concentrations decreased during the first 24 $\mathrm{h}$ and almost totally depleted by day 3 . In contrast, the glucose level in the other doughs increased considerably during fermentation. The wholewheat flour doughs had a higher glucose concentration than the durum flour doughs. After fermentation, $67.7 \pm 3.1 \mathrm{mg} / \mathrm{g}$ and $63.7 \pm 3.5 \mathrm{mg} / \mathrm{g} \mathrm{dw}$ of glucose were found in wholewheat inoculated dough and wholewheat control dough, respectively.

Before the fermentation, no detectable levels of organic acids were found in any of the doughs (Fig. 2B-D). On day $1,11.2 \pm 1.2 \mathrm{mg} / \mathrm{g}$ and $10.3 \pm 0.3 \mathrm{mg} / \mathrm{g}$ dw of LA were already measured in the durum and wholewheat flour control doughs, 
260

261

262

263

264

respectively. Notably, in the matching doughs inoculated with $P$. freudenreichii, the

LA level was $<0.5 \mathrm{mg} / \mathrm{g}$ dw. After day 1 , the LA contents in these doughs increased, ultimately reaching $62.5 \pm 3.7 \mathrm{mg} / \mathrm{g} \mathrm{dw}$ in durum flour and $62.9 \pm 6.8 \mathrm{mg} / \mathrm{g} \mathrm{dw}$ in wholewheat flour, respectively. In the wheat bran doughs, the amounts of LA were $14.7 \pm 1.7 \mathrm{mg} / \mathrm{g}$ and $23.8 \pm 5.5 \mathrm{mg} / \mathrm{g} \mathrm{dw}$ after 1 day, and on day 7, the levels reached $59.5 \pm 1.2 \mathrm{mg} / \mathrm{g}$ and $78.3 \pm 9.4 \mathrm{mg} / \mathrm{g} \mathrm{dw}$ in inoculated dough and control dough, respectively.

In the inoculated doughs, PA was detected on day 1 and increased to $8.3 \pm 1.1$ $\mathrm{mg} / \mathrm{g}$ and $9.3 \pm 0.9 \mathrm{mg} / \mathrm{g} \mathrm{dw}$ in durum flour and wheat bran, respectively, by the end of fermentation. In the inoculated wholewheat flour dough, PA was not detected on day 1 , but a level of $1.3 \pm 0.2 \mathrm{mg} / \mathrm{g} \mathrm{dw}$ was measured on day 7 . AA was detected from day 1 and further increased during the fermentation. Wheat bran doughs had the highest concentrations of AA during fermentation, reaching up to $16.4 \pm 1.8 \mathrm{mg} / \mathrm{g} \mathrm{dw}$ in the inoculated dough and $7.0 \pm 1.6 \mathrm{mg} / \mathrm{g} \mathrm{dw}$ in the control dough on day 7 .

\subsection{Riboflavin}

At the start of fermentation, the amounts of riboflavin in the doughs of durum flour and wholewheat flour were $0.18 \pm 0.03 \mu \mathrm{g} / \mathrm{g} \mathrm{dw}$ and $0.45 \pm 0.05 \mu \mathrm{g} / \mathrm{g} \mathrm{dw}$, respectively (Fig. 3). After 7-day fermentation, riboflavin concentration increased to $0.42 \pm 0.02 \mu \mathrm{g} / \mathrm{g} \mathrm{dw}$ in durum flour dough and $0.73 \pm 0.03 \mu \mathrm{g} / \mathrm{g} \mathrm{dw}$ in wholewheat flour dough. In contrast, the riboflavin in the wheat bran dough was $1.93 \pm 0.11 \mu \mathrm{g} / \mathrm{g}$ $\mathrm{dw}$ at the beginning and decreased to $1.78 \pm 0.07 \mu \mathrm{g} / \mathrm{g} \mathrm{dw}$ on day 7 .

\subsection{Production of vitamin B12}


The UHPLC chromatograms showed that all the vitamin B12 detected in this study was active B12, and no detectable level of pseudovitamin B12 was observed. In the control doughs, no vitamin B12 was detected during fermentation (Table 3). In the inoculated doughs, $17 \pm 1 \mathrm{ng} / \mathrm{g}$ to $47 \pm 6 \mathrm{ng} / \mathrm{g}$ dw of vitamin B12 was found on day 0 , contributed by the $P$. freudenreichii inoculum. By day 1 , the vitamin B12 contents significantly increased $(p<0.05)$ in the doughs inoculated with P. freudenreichii. From day 1 to day 7, the vitamin B12 content in durum flour inoculated dough did not increase, with a final level of $33 \pm 4 \mathrm{ng} / \mathrm{g} \mathrm{dw}$. In inoculated durum flour dough with cobalt chloride $(0.6 \mu \mathrm{g} / \mathrm{g} \mathrm{dw})$ supplementation, 5.2-fold vitamin B12 $(203 \pm 24 \mathrm{ng} / \mathrm{g}$ dw) was produced by the end of the 7-day fermentation period. On day 3, vitamin B12 concentration in the inoculated wholewheat flour dough was significantly $(p<$ 0.05) higher than in the inoculated durum flour dough, but without a significant $(p>$ $0.05)$ increase afterwards $(87 \pm 10 \mathrm{ng} / \mathrm{g} \mathrm{dw}$ on day 7$)$. In inoculated wheat bran dough, the concentration of vitamin B12 significantly $(p<0.05)$ increased from days 3 to 7 and reached $155 \pm 17 \mathrm{ng} / \mathrm{g} \mathrm{dw}$ at the end of fermentation.

\section{Discussion}

P. freudenreichii DSM 20271 was used as a starter in wheat flours and bran for a 7-day fermentation period to study the possibility of in situ fortification of vitamin B12. The non-sterile cereal materials used in this study had various endogenous microorganisms and enzymes activated during fermentation, which is required to obtain full technological functionality of wheat-based raw materials but also leads to rapid acidification by lactic acid bacteria. The differences in nutritional composition, 
304

endogenous microflora and enzyme activity among the three materials have led to significantly different glucose content, microbiota, acidity, and vitamin B12 content during fermentation.

The increase of glucose content in durum flour and wholewheat flour doughs in the first 3 days was likely due to starch hydrolysis by endogenous amylases. Activities of $\alpha$-amylase in three matrices was measured to explain the difference of glucose content among them during fermentation. A higher content of glucose was found in wholewheat flour doughs than in durum flour doughs, which was not surprising given its higher amylase activity (0.19 units/g vs. 0.12 units/g). However, the amylase activities likely decreased in the later part of fermentation due to the drop in $\mathrm{pH}$, since the optimal $\mathrm{pH}$ of cereal amylases is in the range of 4.5-5.5 (Muralikrishna and Nirmala, 2005). With a lower initial level of available carbohydrates $(11 \mathrm{~g} / 100 \mathrm{~g})$ compared to the content in the other flours $(60-65 \mathrm{~g} / 100 \mathrm{~g})$, the glucose content in wheat bran dough was already depleted by day 3 .

Heterofermentative species of LAB play a central role in spontaneous fermentation and dominate the microbial ecology of sourdough (De Vuyst and Neysens, 2005). In the present study, a low level of endogenous LAB was detected before fermentation; they already dominated after day 1 and caused intensive acidification, resulting in the inhibition of yeast, total aerobic bacteria, and total Enterobacteriaceae growth (Table 2). LAB are able to utilize a wide range of substrates as carbon sources (Juturu and $\mathrm{Wu}, 2015)$. The LA content in wheat bran still increased from days 3 to 7 in wheat bran doughs even though glucose was no 
longer detected.

Considering that P. freudenreichii exhibits a slow growth rate (Falentin et al., 2010), an inoculation level of approximately $9.0 \log$ CFU/g of P. freudenreichii DSM 20271 was used in this study. It has been suggested that growth of LAB could be stimulated by propionic acid bacteria due to the consumption of LA and the stimulatory effect of fatty acids produced by propionic acid bacteria (Smid and Lacroix, 2013). In this study, a stimulatory effect of $P$. freudenreichii on LAB growth was not observed in durum and wholewheat flour doughs. The stimulation of LAB growth by $P$. freudenreichii, however, could be observed in the inoculated wholewheat flour dough where the viable cell count of LAB was higher than in the corresponding control dough on day 3 (ca. $9.0 \log \mathrm{CFU} / \mathrm{g}$ and $8.5 \log \mathrm{CFU} / \mathrm{g}$, respectively). Influence of the $P$. freudenreichii starter on the growth of other microbial groups was not observed.

$P$. freudenreichii grew to higher cell densities in durum flour dough compared to the other doughs in the first day of fermentation. However, the cell densities did not increase from day 1 to 7 , possibly due to the unfavorable $\mathrm{pH}$ for $P$. freudenreichii (Deptula et al., 2017b). In the wholewheat flour dough, $P$. freudenreichii did not grow despite a sufficient carbon source and favorable $\mathrm{pH}$ on day 1 . In the wheat bran dough, $P$. freudenreichii grew to lower cell density than in durum flour dough. No growth of $P$. freudenreichii in wholewheat and growth to lower cell densities in wheat bran doughs than in durum flour dough may be due to the presence of some $P$. freudenreichii inhibiting components or endogenous microorganisms in the wheat 
348

bran layer. For instance, it has been shown that flavonoids in buckwheat bran had antibacterial activities against Propionibacterium (Cutibacterium) acnes (Wang et al., 2013). However, to the best of our knowledge, there is no published information available about $P$. freudenreichii inhibiting factors from wheat.

P. freudenreichii metabolizes LA as the preferred carbon source in cheese fermentation to produce PA and AA as the main metabolites (Lee et al., 1974). In this study, LA contents were lower in inoculated doughs than they were in corresponding control doughs, indicating that $P$. freudenreichii consumed LA produced during the fermentation. Since in control doughs PA amounts remained below detection limit, $P$. freudenreichii starter is the likely source of PA in inoculated doughs. In this study, the production of PA did not increase after day 3, which was likely due to the formation of an acidic environment $(\mathrm{pH}<4)$. In contrast, the AA contents still increased from day 3 to 7 in all inoculated dough types, potentially produced by both $P$. freudenreichii and LAB.

No vitamin B12 was detected in the control doughs, showing that vitamin B12 was only synthesized by inoculated $P$. freudenreichii. In an optimized medium supplemented with cobalt and DMBI, vitamin B12 production depended on cell yield (Hugenschmidt et al., 2011). In the present study, the lowest production of vitamin B12 and the highest cell yield of P. freudenreichii was observed in the durum flour dough. In contrast, a more than 2-fold level of production of vitamin B12 was evident in wholewheat flour doughs, while no increase in the cell number of $P$. freudenreichii was observed. In wheat bran doughs, about a 5-fold level of vitamin B12 content was 
detected, with lower growth compared to those in durum flour dough. These results can partly be explained by the higher content of cobalt in wheat bran: $c a .0 .1 \mu \mathrm{g} / \mathrm{g} \mathrm{dw}$ compared to white flour $c a .<0.01 \mu \mathrm{g} / \mathrm{g}$ dw (Ekholm et al., 2007), since cobalt is a limiting factor for vitamin B12 production by $P$. freudenreichii during fermentation (Berry and Bullerman, 1966; Hugenschmidt et al., 2011). Notably, in durum flour dough with added cobalt $(0.6 \mu \mathrm{g} / \mathrm{g}$, dw), more than $200 \mathrm{ng} / \mathrm{g}$ dw of vitamin B12 (vs. ca. $33 \mathrm{ng} / \mathrm{g} \mathrm{dw}$ without cobalt) was produced by $P$. freudenreichii.

In this study, the vitamin B12 produced during fermentation was composed of the active form, with DMBI as a lower ligand (data not shown). Given that no supplements were added, the DMBI in the biosynthesized vitamin was likely derived from de novo biosynthesis by $P$. freudenreichii. Riboflavin has been demonstrated to be the precursor for the de novo biosynthesis of DMBI in the presence of oxygen in $P$. freudenreichii (Hollriegl et al., 1982). Furthermore, riboflavin could be used together with nicotinamide to enhance production of vitamin B12 with some P. freudenreichii strains and a significant positive correlation was observed when comparing riboflavin consumption with B12 production (Chamlagain et al., 2016). The higher riboflavin content in wheat bran (ca. $1.93 \mu \mathrm{g} / \mathrm{g} \mathrm{dw})$ and wholewheat flour $(c a .0 .45 \mu \mathrm{g} / \mathrm{g} \mathrm{dw})$ than in durum flour $(c a .0 .18 \mu \mathrm{g} / \mathrm{g} \mathrm{dw})$ may partly explain the higher levels of vitamin B12 produced in these matrices. In addition, riboflavin can be synthesized by $P$. freudenreichii and certain LAB, such as Lactobacillus plantarum, Lactobacillus lactis, Lactobacillus fermentum and Leuconostoc mesenteroides, commonly retrieved from flour and sourdough microflora (Burgess et al., 2009; Capozzi et al., 2011; 
392

393

Russo et al., 2014). Moreover, some strains of LAB isolated from wheat sourdough were used to enhance the riboflavin content of sourdough and pasta (Capozzi et al., 2011; Russo et al., 2014). In our study, content of riboflavin significantly increased during fermentation in doughs of durum flour and wholewheat flour but not in wheat bran dough (Figure 3). This difference may be due to a distinct microbiota of the flours and bran or riboflavin synthesized by the inoculated $P$. freudenreichii in each dough types. Furthermore, whether riboflavin is a factor for enhancing the production of vitamin B12 in non-sterile wheat materials should be confirmed in future studies.

Bran is the main byproduct of the milling process, which is underutilized for food purposes due to its negative effect on the rheological or sensory quality of products (Prückler et al., 2014). However, the use of bran in food products has been increasing recently due to its high levels of dietary fiber, good quality proteins, and many other beneficial substances. Furthermore, some promising bioprocessing techniques have been proposed to improve the technological and nutritional quality of bran (Coda et al., 2015). In the present study, bran and bran-containing flour were confirmed as potential substrates for plant-based vitamin B12 fortification. These fermented vitamin B12-containing matrices could be used, e.g., in bread baking or in other food products. According to a recent study (Edelmann et al., 2016), in situ synthesized vitamin B12 was as stable as cyanocobalamin, the most stable form of vitamin B12, in baking processes. No significant loss was observed in straight/sponge-dough processes, whereas a loss of only $23 \%$ was reported in sourdough baking (Edelmann et al., 2016). In this study, around $150 \mathrm{ng} / \mathrm{g}$ dw of vitamin $\mathrm{B} 12$ was synthesized in 
414 fermented wheat bran dough by $P$. freudenreichii. If in straight-dough baking, $20 \%$ of

415 wheat flour was replaced with B12-rich wheat bran, four slices of bread (120 g)

416 would contain the recommended daily intake of vitamin B12 $(2.4 \mu \mathrm{g})$. Furthermore,

417 process optimization measures, such as adjusting the $\mathrm{pH}$ and adding ingredients with

418 higher amounts of cobalt (e.g., yeast extract and buckwheat leaf flour; (Grembecka

419 and Szefer, 2006), could be studied to enhance the production of vitamin B12 in

420 wheat materials with $P$. freudenreichii.

421

422

\section{Conclusion}

In previous studies, vitamin B12 production in sterilized cereal matrices has been reported. However, this study demonstrated that nutritionally significant amounts of vitamin B12 can be produced in non-sterile wheat doughs by $P$. freudenreichii. Different wheat ingredients are thus promising option for in situ fortification of plantbased food with vitamin B12. The higher vitamin B12 production in bran and wholewheat flour suggests that outer layers of wheat grain might contain more potential precursors and other factors for vitamin B12 synthesis than white wheat flour. However, a safe use of these wheat matrices for B12 production requires controlling endogenous microbiota with appropriate co-culture fermentation.

\section{Acknowledgements}

Chong Xie acknowledges the China Scholarship Council for its financial support of this work.

\section{References}

Berry, E.C., Bullerman, L.B., 1966. Use of cheese whey for vitamin b12 production .2. Cobalt precursor and aeration levels. Applied Microbiol. 14, 356-357. Bhushan, B., Tomar, S.K., Chauhan, A., 2017. Techno-functional differentiation of 
two vitamin B12 producing Lactobacillus plantarum strains: an elucidation for diverse future use. Appl. Microbiol. Biotechnol. 101, 697-709.

Burgess, C.M., Smid, E.J., van Sinderen, D., 2009. Bacterial vitamin B2, B11 and B12 overproduction: An overview. Int. J. Food Microbiol. 133, 1-7.

Capozzi, V., Menga, V., Digesu, A.M., De Vita, P., van Sinderen, D., Cattivelli, L., Fares, C., Spano, G., 2011. Biotechnological production of vitamin B2-enriched bread and pasta. J. Agric. Food. Chem. 59, 8013-8020.

Chamlagain, B., Deptula, P., Edelmann, M., Kariluoto, S., Grattepanche, F., Lacroix, C., Varmanen, P., Piironen, V., 2016. Effect of the lower ligand precursors on vitamin B12 production by food-grade Propionibacteria. LWT - Food Sci. Technol. 72, 117124.

Chamlagain, B., Edelmann, M., Kariluoto, S., Ollilainen, V., Piironen, V., 2015. Ultra-high performance liquid chromatographic and mass spectrometric analysis of active vitamin B12 in cells of Propionibacterium and fermented cereal matrices. Food Chem. 166, 630-638.

Chamlagain, B., Sugito, T., Deptula, P., Edelmann, M., Kariluoto, S., Varmanen, P., Piironen, V., 2017. In situ production of active vitamin B12 in cereal matrices using Propionibacterium freudenreichii. Food Sci. Nutr. 00, 1-10.

Coda, R., Karki, I., Nordlund, E., Heinio, R.L., Poutanen, K., Katina, K., 2014. Influence of particle size on bioprocess induced changes on technological functionality of wheat bran. Food Microbiol. 37, 69-77.

Coda, R., Katina, K., Rizzello, C.G., 2015. Bran bioprocessing for enhanced functional properties. Curr. Opin. Food Sci 1, 50-55.

Crofts, T.S., Seth, E.C., Hazra, A.B., Taga, M.E., 2013. Cobamide structure depends on both lower ligand availability and CobT substrate specificity. Chem Biol 20, 1265 1274.

De Vuyst, L., Neysens, P., 2005. The sourdough microflora: biodiversity and metabolic interactions. Trends Food Sci. Technol. 16, 43-56.

Denkova, R., Ilieva, S., Denkova, Z., Georgieva, L., Yordanova, M., Nikolova, D., Evstatieva, Y., 2014. Production of wheat bread without preservatives using sourdough starters. Biotechnol. Biotechnol. Equip. 28, 889-898.

Deptula, P., Chamlagain, B., Edelmann, M., Sangsuwan, P., Nyman, T.A., Savijoki, K., Piironen, V., Varmanen, P., 2017a. Food-Like Growth Conditions Support Production of Active Vitamin B12 by Propionibacterium freudenreichii 2067 without DMBI, the Lower Ligand Base, or Cobalt Supplementation. Frontiers in microbiology 8,368 .

Deptula, P., Kylli, P., Chamlagain, B., Holm, L., Kostiainen, R., Piironen, V., Savijoki, K., Varmanen, P., 2015. BluB/CobT2 fusion enzyme activity reveals mechanisms responsible for production of active form of vitamin B12 by Propionibacterium freudenreichii. Microbial Cell Factories 14, 186.

Deptula, P., Laine, P.K., Roberts, R.J., Smolander, O.P., Vihinen, H., Piironen, V., Paulin, L., Jokitalo, E., Savijoki, K., Auvinen, P., Varmanen, P., 2017b. De novo assembly of genomes from long sequence reads reveals uncharted territories of Propionibacterium freudenreichii. BMC Genomics 18, 790. 
Edelmann, M., Chamlagain, B., Santin, M., Kariluoto, S., Piironen, V., 2016. Stability of added and in situ-produced vitamin B12 in breadmaking. Food Chem. 204, 21-28. Ekholm, P., Reinivuo, H., Mattila, P., Pakkala, H., Koponen, J., Happonen, A., Hellström, J., Ovaskainen, M.-L., 2007. Changes in the mineral and trace element contents of cereals, fruits and vegetables in Finland. J. Food Compos. Anal. 20, 487495.

Falentin, H., Deutsch, S.M., Jan, G., Loux, V., Thierry, A., Parayre, S., Maillard, M.B., Dherbecourt, J., Cousin, F.J., Jardin, J., Siguier, P., Couloux, A., Barbe, V., Vacherie, B., Wincker, P., Gibrat, J.F., Gaillardin, C., Lortal, S., 2010. The complete genome of Propionibacterium freudenreichii CIRM-BIA1, a hardy actinobacterium with food and probiotic applications. PLoS One 5, e11748.

Green, R., Allen, L.H., Bjorke-Monsen, A.L., Brito, A., Gueant, J.L., Miller, J.W., Molloy, A.M., Nexo, E., Stabler, S., Toh, B.H., Ueland, P.M., Yajnik, C., 2017. Vitamin B12 deficiency. Nat. Rev. Disease Primers 3, 17040.

Grembecka, M., Szefer, P., 2006. Mineral Components in Food Crops, Beverages, Luxury Food, Spices, and Dietary Food, Mineral Components in Foods. CRC Press, pp. 231-322.

Hollriegl, V., Lamm, L., Rowold, J., Horig, J., Renz, P., 1982. Biosynthesis of vitamin-b12 - different pathways in some aerobic and anaerobic microorganisms. Arch. Microbiol. 132, 155-158.

Hugenschmidt, S., Schwenninger, S.M., Lacroix, C., 2011. Concurrent high production of natural folate and vitamin B12 using a co-culture process with Lactobacillus plantarum SM39 and Propionibacterium freudenreichii DF13. Process Biochem. 46, 1063-1070.

Institute of Medicine, 1998. Dietary reference intakes for thiamin, riboflavin, niacin, vitamin B6, folate, vitamin B12, pantothenic acid, biotin, and choline. . National Academy Press, Washington, D.C.

Juturu, V., Wu, J.C., 2015. Microbial production of lactic acid: the latest development. Crit. Rev. Biotechnol. 36, 967-977.

Lee, I.H., Fredrick.Ag, Tsuchiya, H.M., 1974. Diauxic growth of propionibacteriumshermanii. Applied Microbiol. 28, 831-835.

Malik, A.C., Reinbold, G.W., Vedamuthu, E.R., 1968. An evaluation of taxonomy of propionibacterium. Can. J. Microbiol. 14, 1185-1191.

Martens, J.H., Barg, H., Warren, M.J., Jahn, D., 2002. Microbial production of vitamin B12. Appl. Microbiol. Biotechnol. 58, 275-285.

Muralikrishna, G., Nirmala, M., 2005. Cereal $\alpha$-amylases - an overview. Carbohydr. Polym. 60, 163-173.

Nielsen, M.J., Rasmussen, M.R., Andersen, C.B., Nexo, E., Moestrup, S.K., 2012. Vitamin B12 transport from food to the body's cells--a sophisticated, multistep pathway. Nat. Rev. Gastroenterol. Hepatol. 9, 345-354.

Prückler, M., Siebenhandl-Ehn, S., Apprich, S., Höltinger, S., Haas, C., Schmid, E., Kneifel, W., 2014. Wheat bran-based biorefinery 1: Composition of wheat bran and strategies of functionalization. LWT - Food Sci. Technol. 56, 211-221.

Russo, P., Capozzi, V., Arena, M.P., Spadaccino, G., Dueñas, M.T., López, P., 
Fiocco, D., Spano, G., 2014. Riboflavin-overproducing strains of Lactobacillus fermentum for riboflavin-enriched bread. Appl. Microbiol. Biotechnol. 98, 3691-3700. Santos, F., Vera, J.L., Lamosa, P., de Valdez, G.F., de Vos, W.M., Santos, H., Sesma, F., Hugenholtz, J., 2007. Pseudovitamin $\mathrm{B}(12)$ is the corrinoid produced by Lactobacillus reuteri CRL1098 under anaerobic conditions. FEBS Lett. 581, 48654870.

Smid, E.J., Lacroix, C., 2013. Microbe-microbe interactions in mixed culture food fermentations. Curr. Opin. Biotechnol. 24, 148-154.

Stupperich, E., Nexo, E., 1991. Effect of the cobalt-N coordination on the cobamide recognition by the human vitamin B12 binding proteins intrinsic factor, transcobalamin and haptocorrin. Eur. J. Biochem. 199, 299-303.

Taranto, M.P., Vera, J.L., Hugenholtz, J., De Valdez, G.F., Sesma, F., 2003. Lactobacillus reuteri CRL1098 Produces Cobalamin. J. Bacteriol. 185, 5643-5647. Tinzl-Malang, S.K., Rast, P., Grattepanche, F., Sych, J., Lacroix, C., 2015. Exopolysaccharides from co-cultures of Weissella confusa 11GU-1 and Propionibacterium freudenreichii JS15 act synergistically on wheat dough and bread texture. Int. J. Food Microbiol. 214, 91-101.

Wang, L., Yang, X., Qin, P., Shan, F., Ren, G., 2013. Flavonoid composition, antibacterial and antioxidant properties of tartary buckwheat bran extract. Ind. Crops Prod. 49, 312-317.

Watanabe, F., 2007. Vitamin B12 sources and bioavailability. Exp. Biol. Med. 232, 1266-1274. 
570

Table 1 Ingredients and yields of doughs.

\begin{tabular}{cccccc}
\hline Sample & Substrate & Flour & Water & Dough & Starter \\
code & $(\mathrm{g})$ & $(\mathrm{g})$ & yield $^{\mathrm{c}}$ & \\
\hline DF_Pa & Durum flour & 9 & 21 & 333 & P. freudenreichii \\
DF_P+Co & Durum flour & 9 & 21 & 333 & P. freudenreichii \\
DF_C & Durum flour & 9 & 21 & 333 & - \\
WF_P & Wholewheat flour & 9 & 21 & 333 & P. freudenreichii \\
WF_C & Wholewheat flour & 9 & 21 & 333 & - \\
WB_P & Wheat bran & 6 & 24 & 500 & P. freudenreichii \\
WB_C & Wheat bran & 6 & 24 & 500 & \\
\hline
\end{tabular}

571

a P means doughs inoculated with Propionibacterium freudenreichii; C means control

572 doughs.

573

${ }^{\mathrm{b}} \mathrm{DF} \_\mathrm{P}+\mathrm{Co}=$ durum flour dough with addition of $P$. freudenreichii and $0.6 \mu \mathrm{g} / \mathrm{g} \mathrm{dw}$

574 of cobalt chloride.

$575{ }^{\mathrm{c}}$ Dough yield is represented as the amount of dough prepared from 100 parts of flour.

576

577

578

579

580

581

582 
583 Table 2. Microbial counts of Propionibacteria (PAB) on YEL plate, presumptive

584 lactic acid bacteria (LAB) on MRS plate, total aerobic bacteria on PCA plate, total

585 Enterobacteriaceae on VRBGA plate and yeasts on YM plate (log cfu/g). The results

586 are expressed as the mean \pm standard deviation $(\mathrm{n}=3)$.

\begin{tabular}{|c|c|c|c|c|c|c|c|c|}
\hline & \multicolumn{2}{|c|}{ Day 0} & \multicolumn{2}{|c|}{ Day 1} & \multicolumn{2}{|c|}{ Day 3} & \multicolumn{2}{|c|}{ Day 7} \\
\hline & Inoculated* & Control & Inoculated & Control & Inoculated & Control & Inoculated & Control \\
\hline \multicolumn{9}{|c|}{ PAB } \\
\hline DF & $8.7 \pm 0.0^{\mathrm{a}}$ & $<2.0$ & $9.6 \pm 0.1^{\mathrm{c}}$ & $<2.0$ & $9.6 \pm 0.1^{\mathrm{c}}$ & & $9.5 \pm 0.1^{\mathrm{c}}$ & $<2.0$ \\
\hline WF & $8.7 \pm 0.1^{\mathrm{a}}$ & $<2.0$ & $8.7 \pm 0.1^{\mathrm{a}}$ & $<2.0$ & $8.7 \pm 0.0^{\mathrm{a}}$ & $<2.0$ & $8.6 \pm 0.1^{\mathrm{a}}$ & $<2.0$ \\
\hline WB & $9.0 \pm 0.0^{b}$ & $<2.0$ & $9.4 \pm 0.1^{\mathrm{b}}$ & $<2.0$ & $9.2 \pm 0.1^{\mathrm{b}}$ & $<2.0$ & $9.2 \pm 0.1^{\mathrm{b}}$ & $<2.0$ \\
\hline
\end{tabular}

\section{Presumptive LAB}

$\begin{array}{ccccccccc}\text { DF } & <3.0 & <3.0 & 9.2 \pm 0.0^{\mathrm{b}} & 9.2 \pm 0.0^{\mathrm{b}} & 8.8 \pm 0.0^{\mathrm{ab}} & 8.7 \pm 0.1^{\mathrm{ab}} & 8.4 \pm 0.1^{\mathrm{a}} & 8.5 \pm 0.2^{\mathrm{a}} \\ \text { WF } & <3.0 & <3.0 & 8.6 \pm 0.1^{\mathrm{a}} & 8.6 \pm 0.2^{\mathrm{a}} & 9.0 \pm 0.1^{\mathrm{b}} & 8.5 \pm 0.1^{\mathrm{a}} & 9.0 \pm 0.1^{\mathrm{b}} & 8.7 \pm 0.2^{\mathrm{ab}} \\ \text { WB } & <3.0 & <3.0 & 9.2 \pm 0.1^{\mathrm{b}} & 9.3 \pm 0.1^{\mathrm{b}} & 9.2 \pm 0.1^{\mathrm{c}} & 9.1 \pm 0.1^{\mathrm{bc}} & 9.0 \pm 0.1^{\mathrm{b}} & 9.0 \pm 0.1^{\mathrm{b}}\end{array}$

\section{Total aerobic bacteria}

$\begin{array}{ccccccccc}\text { DF } & 3.6 \pm 0.1^{\mathrm{b}} & 3.6 \pm 0.1^{\mathrm{b}} & 9.2 \pm 0.1^{\mathrm{b}} & 9.2 \pm 0.1^{\mathrm{b}} & 8.9 \pm 0.2^{\mathrm{ab}} & 9.1 \pm 0.1^{\mathrm{b}} & 8.5 \pm 0.1^{\mathrm{a}} & 8.3 \pm 0.1^{\mathrm{a}} \\ \text { WF } & 3.3 \pm 0.1^{\mathrm{a}} & 3.3 \pm 0.1^{\mathrm{a}} & 8.8 \pm 0.1^{\mathrm{a}} & 8.8 \pm 0.1^{\mathrm{a}} & 8.9 \pm 0.1^{\mathrm{ab}} & 8.6 \pm 0.3^{\mathrm{a}} & 9.0 \pm 0.1^{\mathrm{b}} & 8.8 \pm 0.2^{\mathrm{b}} \\ \text { WB } & 3.4 \pm 0.1^{\mathrm{a}} & 3.4 \pm 0.1^{\mathrm{a}} & 9.3 \pm 0.1^{\mathrm{b}} & 9.2 \pm 0.1^{\mathrm{b}} & 9.1 \pm 0.1^{\mathrm{b}} & 9.2 \pm 0.1^{\mathrm{b}} & 9.0 \pm 0.1^{\mathrm{b}} & 8.8 \pm 0.1^{\mathrm{b}}\end{array}$

\section{Total Enterobacteriaceae}

$\begin{array}{ccccccccc}\text { DF } & 4.9 \pm 0.0^{\mathrm{b}} & 4.9 \pm 0.0^{\mathrm{b}} & 6.8 \pm 0.1^{\mathrm{ab}} & 6.6 \pm 0.1^{\mathrm{a}} & <2.0 & <2.0 & \mathrm{nd}^{* *} & \mathrm{nd} \\ \text { WF } & 4.5 \pm 0.1^{\mathrm{a}} & 4.5 \pm 0.1^{\mathrm{a}} & 7.3 \pm 0.1^{\mathrm{c}} & 7.4 \pm 0.1^{\mathrm{c}} & 5.3 \pm 0.1^{\mathrm{b}} & 5.2 \pm 0.2^{\mathrm{b}} & \mathrm{nd} & \mathrm{nd} \\ \text { WB } & 4.5 \pm 0.1^{\mathrm{a}} & 4.5 \pm 0.1^{\mathrm{a}} & 6.9 \pm 0.0^{\mathrm{b}} & 6.8 \pm 0.1^{\mathrm{ab}} & 4.1 \pm 0.1^{\mathrm{a}} & 4.1 \pm 0.0^{\mathrm{a}} & \mathrm{nd} & \mathrm{nd}\end{array}$

\section{Yeasts}

\begin{tabular}{ccccccccc} 
DF & $3.8 \pm 0.0$ & $3.8 \pm 0.0$ & $4.3 \pm 0.1^{\mathrm{a}}$ & $4.3 \pm 0.0^{\mathrm{a}}$ & $<2.0$ & $<2.0$ & nd & nd \\
WF & $<2.0$ & $<2.0$ & $4.8 \pm 0.1^{\mathrm{b}}$ & $4.9 \pm 0.2^{\mathrm{b}}$ & $<2.0$ & $<2.0$ & nd & nd \\
WB & $<2.0$ & $<2.0$ & $5.3 \pm 0.0^{\mathrm{c}}$ & $5.3 \pm 0.1^{\mathrm{c}}$ & $<2.0$ & $<2.0$ & nd & nd \\
\hline
\end{tabular}

587 * "Inoculated" denotes doughs inoculated with Propionibacterium freudenreichii;

588 "Control" refers to doughs without inoculation.

$589 \quad{ }^{* *}$ nd $=$ not detected.

$590 \mathrm{DF}=$ durum flour; $\mathrm{WF}=$ wholewheat flour; $\mathrm{WB}=$ wheat bran.

591 Values from the same day and microbial group bearing different superscripts $(\mathrm{a}-\mathrm{c})$ are

592 significantly different $(\mathrm{p}<0.05)$. 
593

594

\begin{tabular}{ccccc}
\hline Time $(d)$ & 0 & 1 & 3 & 7 \\
\hline Inoculated $^{*}$ & & & & \\
DF & $19 \pm 2^{\text {aw }}$ & $37 \pm 1^{\text {ax }}$ & $40 \pm 3^{\text {ax }}$ & $33 \pm 4^{\text {ax }}$ \\
DF+Co & $17 \pm 1^{\text {aw }}$ & $-* *$ & - & $203 \pm 24^{\text {dx }}$ \\
WF & $17 \pm 2^{\text {aw }}$ & $34 \pm 3^{\text {ax }}$ & $78 \pm 8^{\text {by }}$ & $87 \pm 10^{\text {by }}$ \\
WB & $47 \pm 6^{\text {bw }}$ & $81 \pm 8^{\text {bx }}$ & $114 \pm 5^{\text {cy }}$ & $155 \pm 17^{\mathrm{cz}}$
\end{tabular}

Control

\begin{tabular}{lclll} 
DF & nd*** & nd & nd & nd \\
WF & nd & nd & nd & nd \\
WB & nd & nd & nd & nd \\
\hline
\end{tabular}

* "Inoculated" denotes doughs inoculated with Propionibacterium freudenreichii;

596 "Control" refers to doughs without inoculation.

$597 \quad{ }^{* *}$ Not studied.

$598 \quad{ }^{* * *}$ nd $=$ not detected.

$599 \mathrm{DF}=$ Durum flour; $\mathrm{DF}+\mathrm{Co}=$ durum flour dough with addition of $0.6 \mu \mathrm{g} / \mathrm{g} \mathrm{dw}$ cobalt

600 chloride $\mathrm{dw}=$ dry weight; $\mathrm{WF}=$ wholewheat flour; $\mathrm{WB}=$ wheat bran.

601 Values in the same row $(\mathrm{w}-\mathrm{z})$ and same column $(\mathrm{a}-\mathrm{d})$ bearing different superscripts 602 are significantly different $(p<0.05)$.

603

604

605

606 
1

2 Fig. 1. Changes in $\mathrm{pH}$ value (A) and total titratable acidity (TTA) (B) during fermentation. Values are

3 the means and standard deviations of three replicates. DF_P $=$ durum flour dough with

4 Propionibacterium freudenreichii $; \mathrm{WF}_{-} \mathrm{P}=$ wholewheat flour dough with $P$. freudenreichii; $\mathrm{WB}$ - $\mathrm{C}=$

5 wheat bran dough with $P$. freudenreichii. DF_C $=$ durum flour control dough; WF_C $=$ wholewheat flour

6 control dough; WB_C $=$ wheat bran control dough.

7

8 Fig. 2. Concentration (mg/g, dry matter) of glucose (A), lactic acid (B), propionic acid (C) and acetic 9 acid (D) during fermentation. Values are means and standard deviations of 3 replicates. DF_P $=$ durum 10 flour dough with $P$. freudenreichii; WF_P = wholewheat flour dough with P. freudenreichii; WB_P =

Fig. 3 Concentration $(\mu \mathrm{g} / \mathrm{g}$, dry matter) of riboflavin in inoculated doughs at day 0 and day 7 . Values are means and the error bar represents the range of the values from two biological replicates. wheat bran dough with $P$. freudenreichii. DF_C $=$ durum flour control dough; WF_C = wholewheat flour control dough; WB_C = wheat bran control dough.

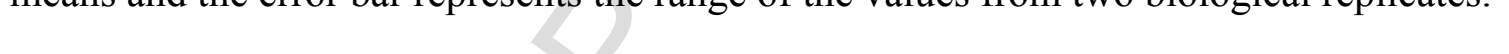


24 Fig. 1.

A

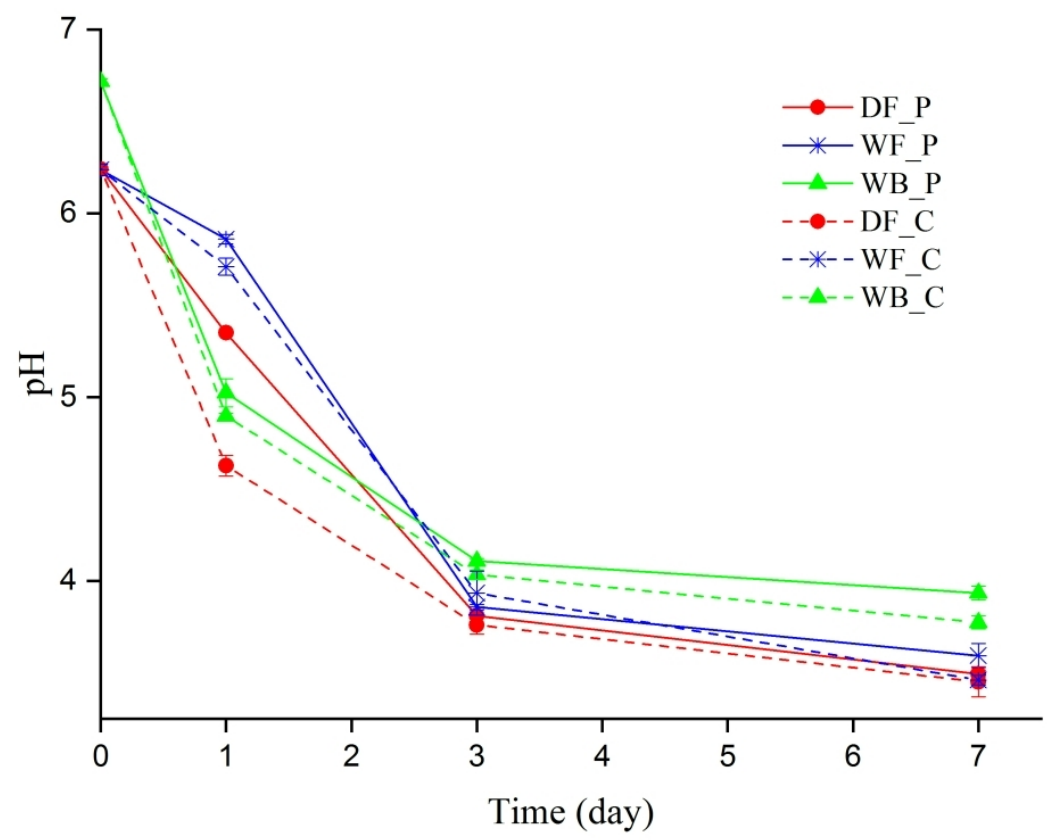

25

B

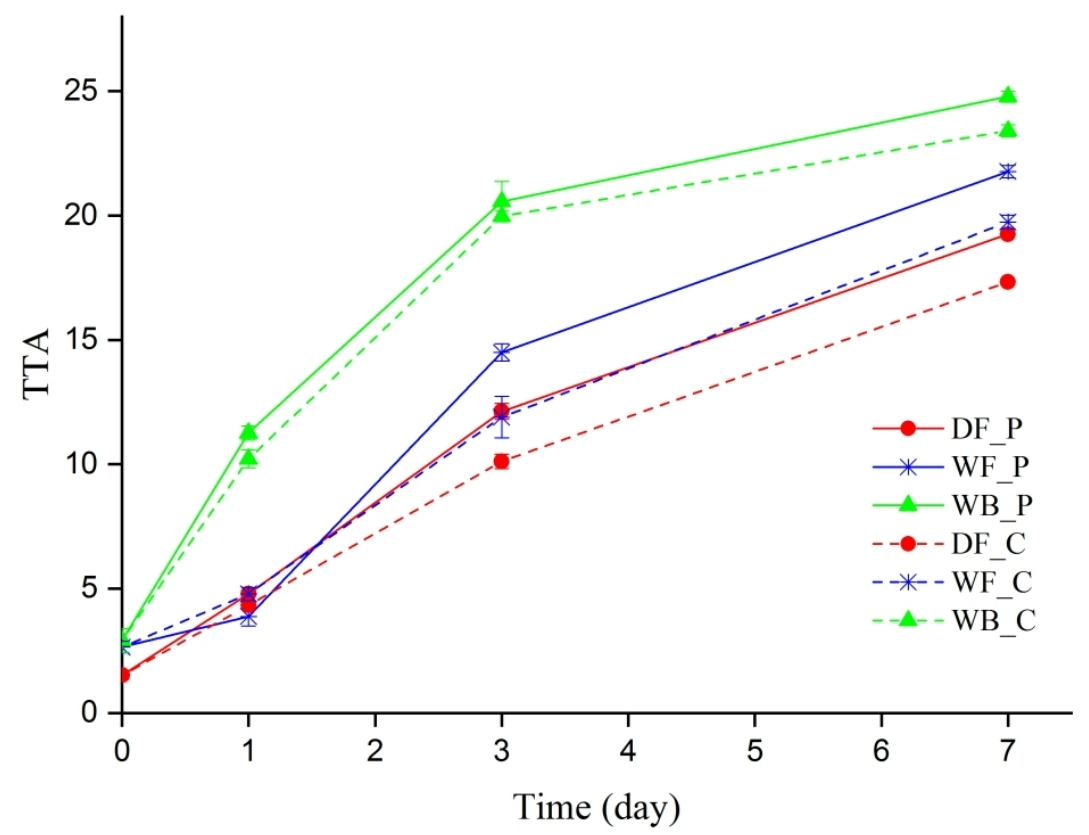


30

Fig. 2.

31

32
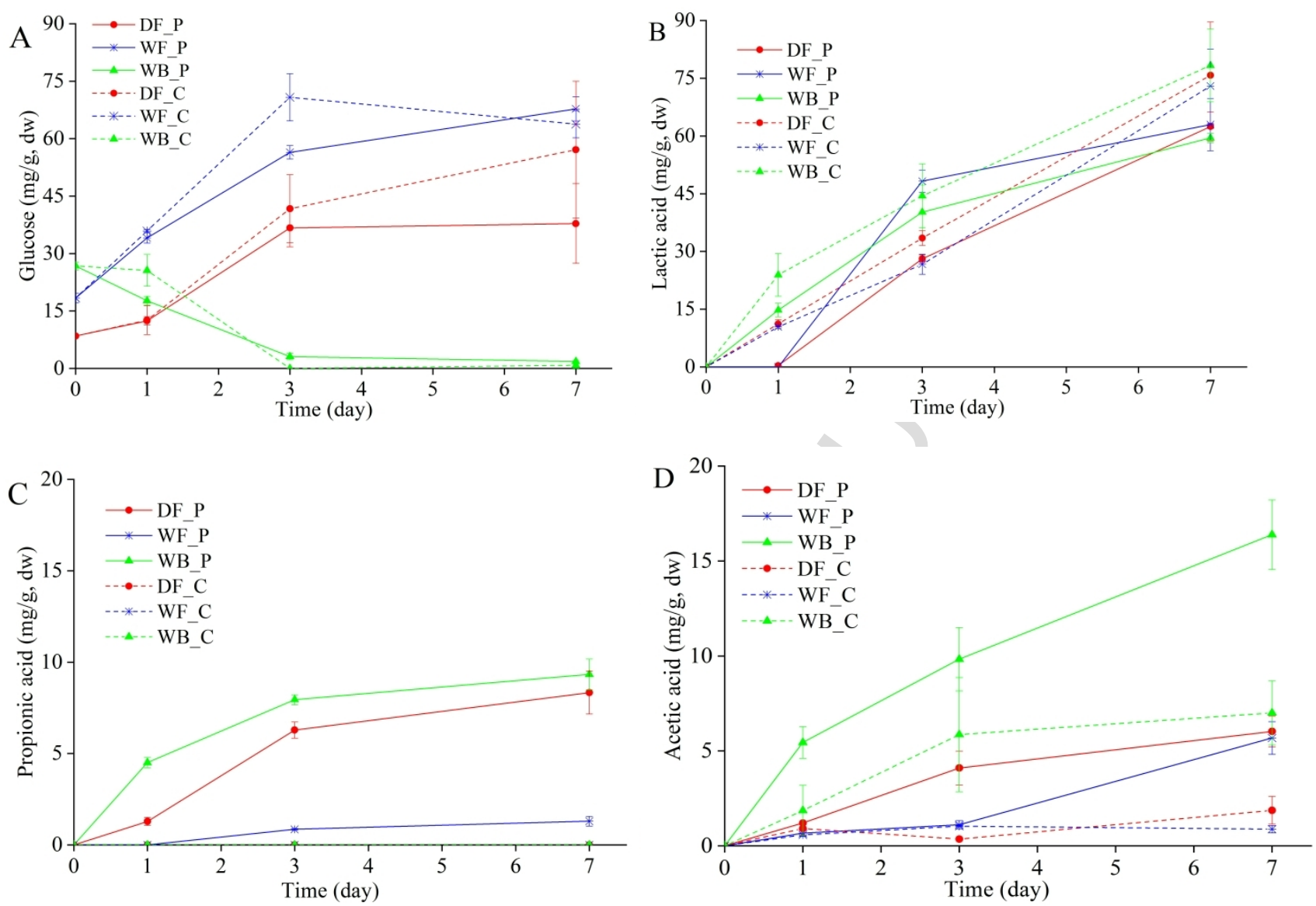

33

34

35

36

37

38

39

40

41

42

43 
$44 \quad$ Fig. 3.

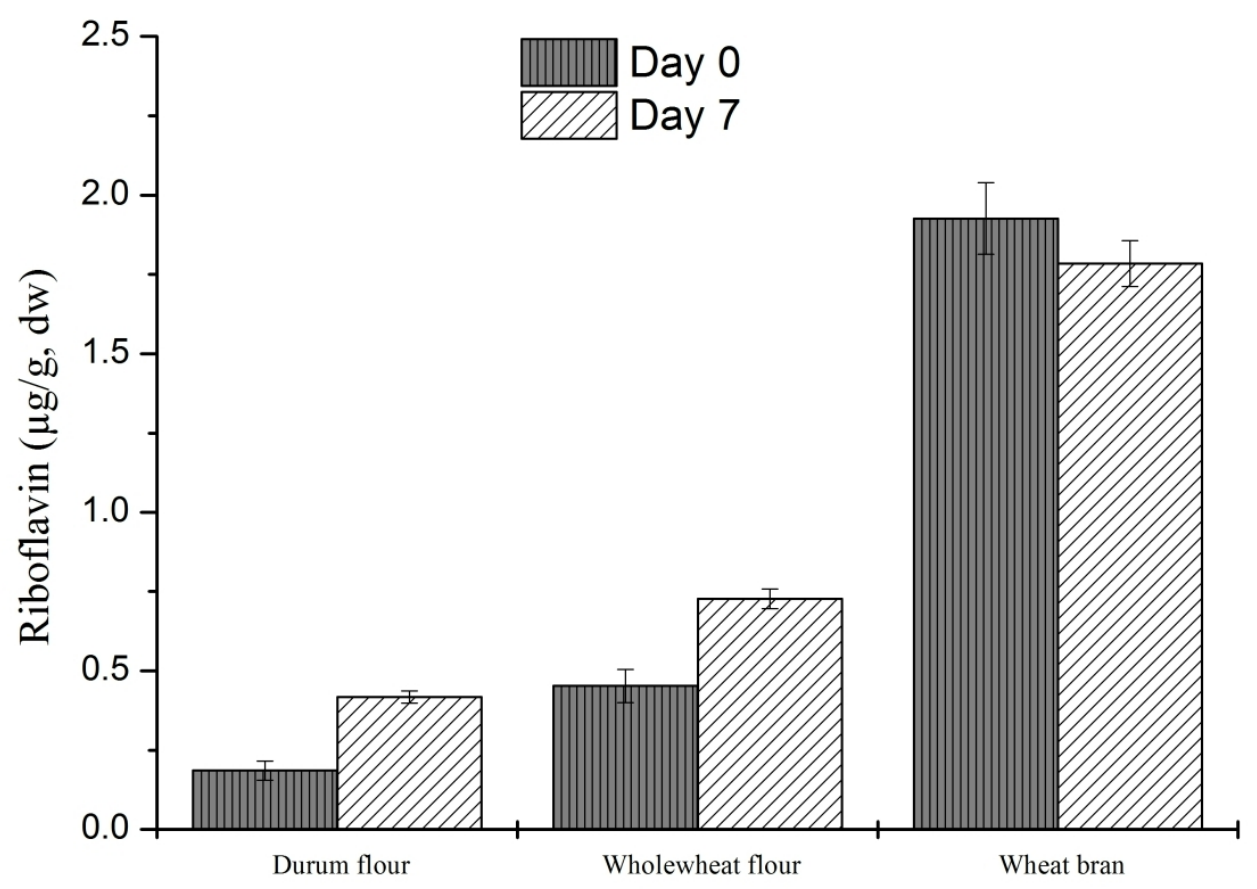

45 


\section{Highlights:}

- Non-sterile wheat matrices maybe used for in situ production of vitamin B12.

- P. freudenreichii produced physiologically relevant amounts of vitamin B12.

- Wheat bran allowed higher production of vitamin B12 than other flours.

- Bran layer possibly contains precursors for vitamin B12 biosynthesis. 